\title{
LEGAL ISSUES RELATED TO THE FLIGHT OF PEASANTS IN OLD POLAND (14TH-19TH CENTURY)
}

\author{
Marcin Konarski*
}

\begin{abstract}
In the light of old Polish law, based on the system of norms of peasant slavery, understood as a legal institution, the flight of peasants was qualified as an illegal act, which was subject various to legal sanctions. The reason why peasants chose to become fugitives was usually their desire to improve living conditions. The direction the fugitives took was another village (a different demesne), a town (private or royal); peasants even crossed state borders. This analysis draws attention to the most important legal problems related to the flight of peasants in old Poland concerning the sources of law as regards the flight of peasants, ways of seeking to release a peasant by means of court proceedings, types of sanctions for such flight, and forms of peasants' abandonment of master's property other than flight.
\end{abstract}

Key words: First Polish Republic, feudalism, peasants, flight of peasants, slave trade, old Polish law

\section{INTRODUCTION}

There are such problems, as T. Manteuffel once wrote, which - although they have long been the target of academic research and have been seemingly solved - are being revisited by almost every generation of re-

* Doctor of legal sciences - Assistant Professor at the Institute of Legal Sciences, Administration and Security, Warsaw Academy of Management. 
searchers trying to present it in a new light ${ }^{1}$. Such problems definitely include legal issues related to the flight of peasants, which are of interest to the study of the history of law and sociology of law, and which will be the subject of this article.

The flight of peasants in old Poland can be analysed as a fight against the feudal system as well as a form of economic migration. One should not forget that the flight of peasants is inseparably linked to their attachment to land, which was the most important aspect of limited personal freedom of the serf ${ }^{2}$, while other limitations also existed, such as limitations of the choice of a spouse and occcupation ${ }^{3}$. The flight of peasants may also

1 See Tadeusz Manteuffel, "Problem feudalizmu polskiego", Przegląd Historyczny 37(1948): 64.

2 See Jan Rutkowski, Historia gospodarcza Polski, vol. I: Czasy przedrozbiorowe, Poznań: Księgarnia Akademicka, 1947, 267-268. For more about the evolution of land ownership in Western Europe, see Józef Kuliszer, Powszechna historia gospodarcza średniowiecza i czasów nowożytnych, volume I, Warszawa: Książka i Wiedza, 1961, 54-65. It was the legal doctrine of as late as the 18th and early 19th centuries that distinguished two types of domicile and three types of serfdom associated with the basic principle of state affiliation. Apart from the proper domicile, i.e. the place of residence with the intention of permanent residence, quasi-domicile, i.e. the place of residence without the intention of permanent residence, was listed. As for serfdom, a distinction was made between temporary and mixed serfs (sujets mixtes) from permanent serfs (whose legal position was taken for granted). Temporary serfs were people who, while temporarily staying on the territory of a given state state, silently surrendered to its laws. Mixed serfs were a category of people with double domicile, Stanisław Grodziski, Poddani mieszani (sujets mixtes) na ziemiach polskich w latach 1772-1815, In: Prawo wczoraj i dziś. Studia dedykowane Profesor Katarzynie Sójce-Zielińskiej w czterdziestolecie pracy naukowej, ed. Grażyna Bałtruszajtys, Warszawa: Liber, 2000, 83-84, note 1. The "mixed subjects" S. Grodziski mentions, were serfs who owned land estates (and thus nobility), in two countries: the Republic of Poland and one of the partitioning countries, i.e. lands detached from Poland. Although the partition treaties guaranteed the mixed serfs that they would not suffer any persecution or additional tax burdens, none of these acts was effective, see Stanisław Grodziski, Poddani mieszani..., 86 and 91. Interesting observations on the concept of the agrarian issue in Poland are presented by Hipolit Grynwaser, Kwestia agrarna i ruch włościan w Królestwie Polskim w pierwszej połowie XIX wieku (1807-1860). Studium archiwalne, In: Hipolit Grynwaser, Pisma, volume II, Wrocław: Zakład Narodowy im. Ossolińskich, 1951, 7-21.

3 See Jan Rutkowski, Historia gospodarcza..., vol. I, 268. 
be seen as a form of economic migration ${ }^{4}$. and economic mobility was always stronger than servitude bonds. Unlike capitalist migrations, which massively transformed peasants into factory workers, spatial migrations in feudal society were horizontal in nature, i.e. in most cases, peasant circulation took place inside a rural community, rarely led to change of their socio-economic status 5 .

The flight of peasants, as one of the forms of fighting against the serfdom system, sometimes made it possible to move permanently to a town ${ }^{6}$, where social and economic living conditions were better than in villages ${ }^{7}$. Moreover, fleeing one's village sometimes provided an opportunity to create an economic situation for the fugitive, which later, in the event that he was found by his lord was, made it easier for him to pay for a permanent exemption from servitude for himself, his wife and children ${ }^{8}$. Regardless of how one assesses the flight of peasants, it was certainly a higher form

4 See Celina Bobińska, Wieś niespokojna. Studia małopolskie z XVIII-XIX wieku, Warszawa: Książka i Wiedza, 1979, 104.

5 See ibidem, 91.

6 Issues the flight of peasants across the boundaries of Poland are analysed in detail by Stanisław Szczotka, Uwagi o zbiegostwie włościan w dawnej Polsce, Rocznik Dziejów Społecznych i Gospodarczych, 11(1949), 132-151.

7 See Maurycy Horn, Walka chłopów czerwonoruskich z wyzyskiem feudalnym w latach 1600-1648. Part I: zbiegostwo i zbójnictwo karpackie, Opole: Wyższa Szkoła Pedagogiczna im. Powstańców Śląskich w Opolu, 1974, 63-64; Stanisław Szczotka, Uwagi o zbiegostwie..., 127-129; Tomasz Opas, O kierunkach awansu społecznego chłopów z dóbr prywatnych w XVIII wieku, In: Społeczeństwo polskie w XVIII i XIX w., Warszawa: Państwowe Wydawnictwo Naukowe, 1974, 60-76.

8 A dozen or so examples are given by Stanisław Szczotka, Zwalnianie chłopów z poddaństwa w województwie krakowskim w latach 1572-1794, Czasopismo Prawno-Historyczne 3(1951), 278-285. Apart from location privileges, location documents, documents for village leaders, documents for villages, rural court books, ordinances and rural acts, as well as economic instructors, exemptions from serfdom are interesting sources of knowledge about rural law, see more Stanisław Kutrzeba, Historia źródeł dawnego prawa polskiego, vol. I, Lwów: Zakład Narodowy im. Ossolińskich, 1925, 318-332. However, as Józef Putek notes, the liberation of the peasant from the land subjugation was rarely practiced. In such cases, the liberation documents were entered into court books, and, as Putek stresses, "such entries can be found extremely rarely in the books, because in those times of peasant slavery the nobility's submissiveness to the peasant - personal property of a nobleman was rare", Józef Putek, Miłościwe pany i krnąbrne chłopy włościany. Szkice i sylwetki z dziejów poddaństwa, pańszczyzny, grabieży wojskowych, procesów sądowych 
of peasants' struggle against the manor and “it was no longer just a protest against the lord's individual demands, but completely breaking off contact with him"'.

Growing serfdom burdens on peasants and accompanying brutal practices of the administration of manors, which often assumed the character of absolute physical coercion (beatings of peasants, up to the loss of health or even life by leaseholders and their servants $)^{10}$, were the reasons for peasants' resistance, being an expression of an open mass fight against feudal exploitation in the Polish countryside ${ }^{11}$, alongside other forms of resistance, such as: evading work on farmland, non-payment of rent, non-payment of tribute, inaccurate and inefficient work of peasants ${ }^{12}$. In addition, the peasants' aspirations to change their material living conditions often manifested themselves in the form of mob action and rebellions ${ }^{13}$, which were often joined by journeymen, i.e. permanent manorial service ${ }^{14}$.

i innych form ucisku społecznego na dawnym pograniczu śląsko-polskim, Kraków: Ludowa Spółdzielnia Wydawnicza, 1969, 98.

9 Stanisław Szczotka, Z dziejów chłopów polskich, Warszawa: Ludowa Spółdzielnia Wydawnicza, 1951, 9.

10 Ryszard Orłowski points out the fact that peasants were subjected to this type of abuse, Opór włościan i formy walki klasowej w Ordynacji Zamojskiej w drugiej połowie XVIII stulecia, Annales Universitatis Mariae Curie-Skłodowska. Sectio F 5(1959), 144-146; Maurycy Horn, Walka klasowa i konflikty społeczne w miastach Rusi Czerwonej w latach 1600-1647 na tle stosunków gospodarczych, Wrocław: Zakład Narodowy im. Ossolińskich, 1972, 172-173. Józef Rafacz explicitely writes about "poverty and harm" being the reason for the flight of peasants, Józef Rafacz, "Sprawa niewoli chłopskiej w dawnej Polsce”, Przewodnik Naukowy i Literacki 48(1920), 467-468.

11 See Maurycy Horn, Walka chłopów..., 34-35; Historia chłopów śląskich, ed. Stefan Inglot, Warszawa: Ludowa Spółdzielnia Wydawnicza, 1979, 163-164.

12 See Ryszard Orłowski, Opór włościan..., 146-153. An interesting case of the evasion of obligatory free labour for the lord is reported by Krzysztof Ruszel, Sprawy chłopskie przed sądem dominialnym w Nienadowej w latach 1806-1843, Przemyśl: Krajowa Agencja Wydawnicza, 1989, 128-129.

13 See Ryszard Orłowski, Opór włościan..., 160-167; Hipolit Grynwaser, Przywódcy i „burzyciele” włościan, In: Hipolit Grynwaser, Pisma..., vol. II, 213-263. In addition, it should be remembered that some fugitive serfs did not flee to another master, but often became ruffians. For example, runaway peasants from the Podhale region merged with mountain gangs of bandits, consisting mostly of Hungarians, Czechs, Slovaks and Germans, and together with them attacked manors and castles, see Zdzisław Wróbel, Zbójnictwo na Podhalu, Częstochowa: Drukarnia Udziałowa, 1929, 11. 
Sometimes peasants' flight resulted in their release from serfdom. This usually happened when peasants about 10 years before, or sometimes even much earlier, fled from their lords' village and settled elsewhere, e.g. in a town ${ }^{15}$, where they were granted town citizenship, working

14 See ibidem, 164-165; Bohdan Baranowski, Ludzie luźni w południowo-wschodniej Wielkopolsce w XVII-XVIII wieku, Łódź: Zakład Narodowy im. Ossolińskich, 1953, 8. Czeladź (manorial servants) were mainly personal service, used more often for needs and services in the manor than for agricultural work on the farm, but we do not mean the "professional" group of farm servants that was established later on. Flight consisted in a group of people giving up working without notice and running away secretly at night, as well as not showing up for work at the manor despite taking a deposit. The flight of czeladź was classified as a crime and prosecuted by the state institutions, but not, as in previous centuries due to the peasant's dependence on the manor, but because of the heirs' financial claims to the fugitives, due to the material losses suffered by the manor farm as a result of an unforeseen loss of labour force. When the fugitive was already in a new place, wójt (the mayor of the gmina district) applied on his behalf for a certificate of resettlement to a new place. The party from which he fled then filed an accusation of flight, demanding that the administrative authorities force him to return and impose a financial penalty on the manorial lord and the wójt of the gmina who accepted the fugitive. The legal ways of leaving the service by czeladź prematurely included, among others, abuse of domestic punishment and bad nutrition, withholding payment or failure to observe other conditions of the agreement, see Halina Chamerska, O położeniu i zbiegostwie czeladzi folwarcznej w Królestwie Polskim 1830-1864, Warszawa: Państwowe Wydawnictwo Naukowe, 1957, 10, 12-13, 27, 35; Bohdan Baranowski, Ludzie luźni..., 10-11. It should be noted that from 1807, czeladź and the entire rural population remained free, because the Constitution of the Duchy abolished serfdom, and the decree of December ensured the freedom of changing the place of residence, after the administrative and police obligations had been met, while in practice the relics of serfdom were more burdensome for this group of the rural population than for peasants. As far as the legislation is concerned, attention should be drawn to the decision of the Administrative Council on servants and czeladź of 26 April 1817 (publication place missing, 1817, p. 40); the decision of the Governor of 30 May 1818 on the organisation of rural gmina districts (Journal of Laws of the Kingdom of Poland, vol. 6, pp. 34-41); regulation of the Commission of the Mazovia Voivodeship of 30 January 1820 prohibiting leaseholders of government property from forcing the population to serve in the manor and from getting servants to the manor by the village leaders of particular communities (Official Journal of the Voivodeship of Mazovia, 1820 , no. 203, supplement, p. 7313). For more about the peasant legislation in this period see Konstanty Grzybowski, Burżuazja a obszarnicy w państwie obszarniczo-burżuazyjnym ( $Z$ zagadnień ustroju społeczno-gospodarczego), Kwartalnik Historyczny 4-5(1956), 221-244, in particular notes 29, 32-33, 39, 56, 59, 64, 78 and 81.

15 See Maurycy Horn, Walka chłopów..., 44-45. 
in crafts and even reaching considerable wealth. However, when they were found by their former lord or his heirs - not wanting to return to their native village because they were afraid to lose a much more tolerable economic and social situation - they bought out from serfdom ${ }^{16}$. It should be added that fugitives before they settled, had been treated as loose people along the way, because they could not prove their affiliation, but the purpose of their flight was to finally settle down and become a serf subject to better conditions in another village or province ${ }^{17}$.

\section{ANCIENT SOURCES OF POLISH LAW}

As mentioned above, the most important characteristic of serfdom was an attachment to the land, which meant that the surf could not change his place of residence without his master's permission ${ }^{18}$, and the master could recover a wilfully fugitive serf with the help of a public authority. Cases of peasants' flight were related to the failure of a peasant to fulfill his obligations towards the landowner (also in the case of abduction) and for this reason only, the master was entitled to seek the fugitive, or possibly entitled to compensation ${ }^{19}$.

The legislation of old Poland knows numerous regulations concerning this matter ${ }^{20}$. The nobility tried to prevent the flight of peasants through

16 For more see Stanisław Szczotka, Zwalnianie chłopów..., 278-286.

17 See Stanisław Grodziski, Ludzie luźni: studium z historii państwa i prawa polskiego, Kraków: Uniwersytet Jagielloński, 1961, 32-33.

18 As Józef Rafacz emphasises, "in principle, from 1496 it was prohibited to leave even for a short period of time one's village, because there was a fear that the serf would use this opportunity to escape. Therefore, on the basis of the Acts of the Polsh Republic, it was required that each peasant, whether they were going to become a servant or move to a city to learn a craft, should have a written permission from their master", Józef Rafacz, Ustrój wsi samorządnej małopolskiej w XVIII wieku, Lublin: Uniwersytet Lubelski, 1922, 122.

19 Cf. Kazimierz Tymieniecki, Zagadnienie niewoli w Polsce u schyłku wieków średnich, Poznań: Poznańskie Towarzystwo Przyjaciół Nauk, 1933, 18-19.

20 In Silesia, in the sixteenth and seventeenth centuries the flight became so widespread that, as Stefan Inglot emphasises, "the issue of flight and the recovery of fugitive peasants never left the agenda of the Silesian Sejm in Wrocław", Stefan Inglot, Historia chłopów..., 165. 
a system of prohibitions and administrative orders. General Sejm assemblies issued constitutions aimed at hindering the movement of peasants and facilitating the recovery of fugitives. The Sejm's legislation was supplemented by laudas and sejmik instructions, in which the nobility postulated a significant tightening of penalties for not issuing fugitives, demanded that trials should be shortened, and that appeals should be prohibited in cases concerning fugitives and that penalties for detaining fugitives should be increased ${ }^{21}$. As M. Horn emphasizes, attempts were also made to reduce the wave of fugitives through internal regulations, i.e. economic instructors and village laws, which contained a number of instructions for property administrators on how to prevent peasants from escaping, set penalties for insufficient supervision, and sometimes even forced their neighbours to bail them out and in case of escape, the fugitive for whom they bailed was forced to participate in the chase ${ }^{22}$.

As the first sources of law in the aforementioned area at that time, one should mention the statutes of Casimir III the Great, issued separately for Greater Poland (granted in Piotrków Trybunalski) and Lesser Poland (granted in Wiślica) ${ }^{23}$, which, as W. Uruszczak stresses, "were the result of the will to reform the existing customary law"24. "In the light of the Stat-

21 See Volumina Legum, vol. II, Petersburg: J. Ohryzko, 1859, 243 (hereinafter referred to as: VL2); Laudum sejmiku wiszeńskiego z dnia 14 maja 1715 r., In: Akta grodzkie i ziemskie, vol. XXII, prep. by Antoni Prochaska, Lwów: Towarzystwo Naukowe we Lwowie, 1914, 612; Laudum sejmiku ziemskiego w Haliczu z dnia 10 lipca 1774 r., In: Akta grodzkie i ziemskie, vol. XXV, prep. by Wojciech Hejnosz, Lwów: Towarzystwo Naukowe we Lwowie, 1935, 205.

22 See Księgi sądowe wiejskie klucza jazowskiego z lat 1663-1808, prep. by Stanisław Grodziski, Wrocław-Warszawa-Kraków: Zakład Narodowy im. Ossolińskich Wydawnictwo Polskiej Akademii Nauk, 1967, 158-159; Bolesław Ulanowski, Wieś polska pod względem prawnym od wieku XVI do XVIII, Kraków: Akademia Umiejętności, 1894, 31; Maurycy Horn, Walka chłopów..., 58-59 and 192; Stanisław Szczotka, Uwagi o zbiegostwie..., 169-170. In any case, peasants were often used by masters to chase the fugitives, and often peasants on their own initiative, without a warrant, stood up against the fugitives, detained them and returned them to the court, see Stanisław Śreniowski, Zbiegostwo chłopów..., 112.

23 See Volumina Legum, vol. I, Petersburg: J. Ohryzko, 1859, 1-24 (hereinafter referred to as: VL1).

24 Wacław Uruszczak, "Statuty Kazimierza Wielkiego jako źródło prawa polskiego", Studia z Dziejów Państwa i Prawa Polskiego 3(1999), 103. Romuald Hube points out the 
utes," W. Uruszczak further writes, "customary law descended to the level of the source of law subordinate to royal laws (statutes). It was a statute, i.e. a royal statute - judging the custom as good or bad (bona sive mala consuetudo) - that decided whether it was to remain in force as law" ${ }^{25}$. As the time when the statutes of Lesser Poland and Greater Poland were issued, Z. Kaczmarczyk quotes the years 1346-1347, indicating at the same time that their supplementation took place in $1356^{26}$. However, some of the acts, Z. Kaczmarczyk writes, "were published in the meantime, and even later until the death of Casimir the Great, although not all of them were included in the statutes" 27.

The Statute of Wiślica explicitly mentions kmetones and villani, who together constitute a class of people settled in villages, engaged in agriculture, and next to them there are so-called incolae (inhabitants of villages) although the Statute does not give any indication of their situation. R. Hube points out that Świętosław called them "stayers"28. In relation to the heirs of the village in which they settled, villani are called 'serfs' and the heirs of the village are called 'masters' in relation to them. "In order to prevent the devastation of property - R. Hube quotes the provisions of the Statute of Wiślica - as a result of the surfs, i.e. kmetones and other villagers (cmetones aut incolae) leaving them, it was decided at the request of the barons that at one time, without the permission of the master, no more than one or two of them may move to another village ${ }^{29}$. However, an exception to this rule was made in the following cases: (1) if the master of the countryside rapes the daughter or wife of a kmeton, (2) if peasants

difference between the Greater Poland Statute and the Wiślica Statute, see Romuald Hube, Ustawodawstwo Kazimierza Wielkiego, Warszawa: Biblioteka Umiejętności Prawnych, $1881,75-76$.

25 Wacław Uruszczak, Statuty..., 103-104.

26 See Zdzisław Kaczmarczyk, Monarchia Kazimierza Wielkiego. Volume I: organizacja państwa, Poznań: Księgarnia Akademicka, 1939, 86.

27 These are the statutes on transit roads through Poland of 1344, the ordinance on tithes of 1352, the salt ordinance, the statutes on the transport of salt of 1368, the statutes on the duties of starosts of 1368-1370, see Zdzisław Kaczmarczyk, Monarchia..., vol. I, 86.

28 Romuald Hube, Ustawodawstwo..., 111.

29 See Antoni Zygmunt Helcel, Starodawne prawa polskiego pomniki, vol. I, Warszawa: Księgarnia Gustawa Sennewalda, 1856, 21. 
are taken away from their property (bona) through the fault of the master, or finally (3) if peasants all year long are subject to a curse through the fault of their master. In these cases, not only three or four villani can leave the village, but all the people living there (omnes inhabitantes ibidem) and go wherever they like (art. XXXVI. 69)" 30.

According to R. Hube, "out of the twenty-four articles in Part One of the Statute, nine of them, and therefore more than a third, set out provisions designed to provide care for the poor classes of the nation, the poor knights and peasants, and to improve their social situation. Four of them refer exclusively to kmetones ${ }^{31}$, including one which lifts puścina (or: pusczina, opusczyna) in kmeton estates and therefore ensures that the relatives of a deceased childless kmeton receive inheritance ${ }^{32}$, while the other increases the fine for a killed kmeton and allots a part of it towards his relatives ${ }^{33}$. It is likely that the provisions reducing accidental death and restraining the misuse of court servants when they studied corpses were mainly in favor of peasants, as they had the highest number of accidents" 34 . Moreover, also in Part Two of the Statute, villani has been granted more extensive legal protection than hitherto, through: (1) granting kmetones $2 / 3$ of the payment for cuts, injuries or murder; 2) consent to defense in the event of assault by the servants of neighbouring masters stealing grain on a field during the night; (3) securing compensation for the destruction caused by the army; (4) regulating the cases of leaving the premises of kmetones and

30 Ibidem, pp. 21-22; see Romuald Hube, Ustawodawstwo..., 111. In the opinion of Stanisław Czernik, the first researcher of the history of the Polish peasantry was Szymon Starowolski (d. 1656), who, on the basis of the Wiślica Statute and the Sejm constitutions of the 16th century, tried to demonstrate the difference between the notions of serfdom and slavery, at the same time defining Poland as a "hell for peasants" (Polonia est infernus rusticorum), see Stanisław Czernik, Z życia pańszczyźnianego w XVII wieku: materiały i szkice, Warszawa: Ludowa Spółdzielnia Wydawnicza, 1955, 19-21.

31 In the Greater Poland Statute, just as in the Wiślica Statute, the term "kmeton" is used to designate a peasant (villanus). He had a master over him, who was the owner of the village (dominus villae) in which the kmeton lived.

32 Article LIII of the Wiślica Statute is cited in Polish by A.Z. Helcel, Starodawne..., p. 18.

33 See VL1, 11. Article LV of the Wiślica Statute is cited in Polish by Antoni Zygmunt Helcel, Starodawne..., 18.

34 Romuald Hube, Ustawodawstwo..., 179. 
determining the cases in which the entire peasant settlement could leave the village ${ }^{35}$. Such a wording in relation to peasants certainly puts Casimir the Great in a good light; in order to ensure the economic prosperity of the country, he was able to take care of this social class, which had so far had been ignored. As Z. Kaczmarczyk stresses, "the law was supposed to restore the social balance, the ideal of a Christian monarch", which was reflected primarily in the legal protection of the physically weaker, i.e. women and children, and the socially weaker, such as kmetones and poorer knights ${ }^{36}$.

However, we are most interested in the provisions of the Statute concerning the possibility of the expulsion of kmetones from their premises. In accordance with Article XXXIV. 134, the exit of a kmeton from their premises may actually only take place during Christmas, and under the following conditions: "If he had resided in a wola settlement and wanted to displace himself, he should serve his master (suo domino) as many years as he was exempted from all rents, fees, and taxes; kmetones subject to German law could not leave until they had paid their rent for all the years of freedom (quot annis habebant libertatem) and until they had replaced themselves with equally wealthy kmetones or until they had cultivated, grubbed up and sown their fields completely with winter cereal and vegetables ${ }^{37}$.

However, despite the failure to comply with these conditions, the Statute provided for the possibility of escaping from one's master (a domino suo fugere), in the following cases: "1) when the lord was cursed by the church for his misconduct and for this reason the deceased kmetones could not be buried according to church rites; 2 ) when a lord have raped a female peasant, in which case not only the parents of the raped peasant, but all the peasants were allowed to move out (recedere), and the lord of the village could not stop them or cause them any harm; 3) when for the guilt of the lord (ob culpan sui domini) kmetones were accused (pignora fuerint ab eisdem), all the peasants could also escape (article XXXIV. 134)"38.

35 See ibidem, 179-180.

36 See Zdzisław Kaczmarczyk, Kazimierz Wielki (1333-1370), Warszawa: Wydawnictwo S. Arcta, 1948, 129.

37 See Romuald Hube, Ustawodawstwo..., 185.

38 Ibidem, 185. 
Therefore, as we can see, the provisions of the Greater Poland Statute differ in editorial terms from the provisions of the Wiślica Statute, while the analogy concerning the purpose of the regulation was preserved ${ }^{39}$ and both statutes supplement each other.

As far as punishment for killing a kmeton is concerned, the Greater Poland Statute set it at six grzywnas ${ }^{40}$, three of which were intended for the wife or children of the killed person (if he had them) and, in the absence of offspring, those three grzywnas were passed on to the relatives (propinqui) of the killed kmeton, while the other three grzywna (residuae marchae) were paid to the master of the kmeton, but only if both the killer and the killed person had been settled with the same master. If they both belonged to two masters, the three grzywnas were split into two halves ${ }^{41}$. The inclusion of such a provision in the Statute significantly strengthened the legal position of peasants.

The statute of Greater Poland stipulated that a peasant who escaped from a village under Polish law could not legally settle down, i.e. could not conclude a legal agreement at a new place, unless his former master, knowing his new place of residence, took no steps within a year to bring him back using legal measures ${ }^{42}$. The fugitive who was found guilty by the

39 Romuald Hube points out that the characteristic feature of the Greater Poland Statute is the fact that the Statute of Wiślica usually deals with the extension of the legal care over the Peasantry and where it was possible to equalize the position of its social status with that of the higher classes, whereas Greater Poland Statute mainly deals with the insurance of the rights of the Knights in its higher, exceptional position, see Romuald Hube, Ustawodawstwo..., 220. That's what Kaczmarczyk claims: the Greater Poland Statute is "rather a law for knights, preserving their old rights, not taking care of the lower layers of the nation, leaving many crimes to be solved through family revenge and bearing the traits of archaism”, Zdzisław Kaczmarczyk, Monarchia..., vol. I, 96.

40 In old Polish law, depending on the nature of the offense, fines were usually paid with domestic coins. The best-known ones, which are already mentioned in the statute of Wiślice, include: (1) seventeenth penalty (septuaginta) - paid to the king; (2) fifteenth penalty (poena quindecim) - paid to the court and persons asserting their rights and only to the court; (3) most interesting to us, six grzywnas (sex marcarum), see VL1, 15-16; Romuald Hube, Sądy: ich praktyka i stosunki prawne społeczeństwa w Polsce ku schyłkowi 14 wieku, Warszawa: Biblioteka Umiejętności Prawnych, 1886, 234-239.

41 See Romuald Hube, Ustawodawstwo..., 201.

42 See Juliusz Bardach, Historia państwa i prawa Polski do połowy XV wieku, vol. I, ed. II, Warszawa: Państwowe Wydawnictwo Naukowe, 1964, 394. It should be noted that 
court could free himself from his return to the village from which he had escaped by paying his master one year's rent and three grzywnas, i.e. by buying himself out. Later legislation, such as the Warka Statute granted by Władysław Jagiełło in 1423 at the General Sejm ${ }^{43}$, provided the obligation to call on the fugitive to return for four times, and only then the possibility to have a new settler, whose was legally protected from threats from the fugitive $e^{44}$. However, the later Nieszawa Statutes (Privileges) granted by Kazimierz IV Jagiellończyk in 1454 regulated the procedure of handing over the fugitive peasants to their masters in such a way that anyone who did not return, at the request of the master, the fugitive who was staying with him paid a fine of 3 grzywnas to the court, a private fine of the same amount to the master and had to give the fugitive up.

In the cases concerning fugitive peasants, the feudal lords often signed agreements on the mutual surrender of the fugitives ${ }^{45}$ (e.g. the agreement of Prince Siemowit III of Mazovia with the Archbishop of Gniezno of 1359) - moreover, the obligation to return the fugitive to the former master at his request resulted from the aforementioned privileges of Nieszawa. Later, for example, the Constitution of the General Warsaw Sejm of 1578 provided that the surfs who fled or violently captured were entitled to be investigated and reinstated ${ }^{46}$. In turn, the Constitution of the General Crown Sejm in Warsaw of 1609 , mentioning the serfs who fled to the Prussian cities,

the heir did not lose his rights to fugitives even after several decades, see Janusz Deresiewicz, Handel chłopami w dawnej Rzeczypospolitej, Warszawa: Książka i Wiedza, 1958, 178-180.

43 Romuald Hube writes that subject of the legislative convention in Warka was: "to review the legislation remaining after King Casimir [the Great - emphasis mine, M.K.], where it seemed necessary to modify and add new regulations which were deemed necessary", Romuald Hube, Ustawodawstwo..., 84.

${ }_{44}$ Article XXIII of the Warka Statute is cited in Polish by Antoni Zygmunt Helcel, Starodawne..., 322-323; Cf. Kazimierz Tymieniecki, Zagadnienie niewoli..., 29-31.

45 Conflicts between two lords over a fugitive were often resolved amicably, without a trial. Janusz Deresiewicz points out that "when it was impossible to recover a fugitive, it was even better to give him as a gift, at least it was a honourable solution", Janusz Deresiewicz, Handel chłopami..., 183.

46 See VL2, 188. 
stated that if a fugitive serf would ever be found, he should be released ${ }^{47}$. The Declaration of Emperor Leopold V, dated 5 July 1701, forbade the detention of serfs fleeing from Poland and Hungary, ordering them to be handed over to their masters ${ }^{48}$. However, aforementioned K. Tymieniecki is of the opinion that the general attachment of peasants in Poland to the land at the end of the 15th and beginning of the 16th centuries is out of the question, because it is opposed by the Constitution passed later than the Constitution of Piotrków (1496) ${ }^{49}$, i.e. from 1501, according to which there was no universal attachment of peasants at that time ${ }^{50}$. W. Hejnosz points out that "probably in the opinion of the then noble society there was a feeling that the peasant is inseparably connected with the land on

47 See VL2, 467. Provisions related to the recovery of fugitive serfs can be found in the parliamentary instructions., see Instrukcja dana posłom na sejm z sejmiku województwa krakowskiego w Proszowicach 27 stycznia 1597 r., In: Akta sejmikowe województwa krakowskiego, vol. I, prep. by Stanisław Kutrzeba, Kraków: Polska Akademia Umiejętności, 1932, 217; Instrukcja dana posłom na sejm z sejmiku przedsejmowego województwa krakowskiego w Proszowicach 9 grudnia 1636 r., In: Akta sejmikowe województwa krakowskiego, vol. II, prep. by Adam Przyboś, Kraków: Polska Akademia Umiejętności, 1953, 217-218; Instrukcja sejmiku wiszeńskiego posłom na sejm z 15 grudnia 1651 r., 19 maja 1654 r., 28 lutego 1659 r., 23 lutego 1662 r., 15 października 1664 r., In: Akta grodzkie i ziemskie, vol. XXI, prep. by Antoni Prochaska, Lwów: Galicyjski Wydział Krajowy, 1911, 94, 154, 273, 343, 396-397; Instrukcja dana posłowi do króla z sejmiku księstw zatorskiego i oświęcimskiego w Zatorze 4 maja 1667 r., In: Akta sejmikowe województwa krakowskiego, vol. III, prep. by Adam Przyboś, Wrocław-Kraków: Zakład Narodowy im. Ossolińskich Wydawnictwo Polskiej Akademii Nauk, 1959, 171; Instrukcja sejmiku wiszeńskiego posłom na sejm z 22 sierpnia 1740 r., 23 sierpnia 1756 r. i 21 sierpnia 1758 r., In: Akta grodzkie i ziemskie, vol. XXIII, prep. by Antoni Prochaska, Lwów: Towarzystwo Naukowe we Lwowie. 1928, 199, 345, 373.

48 See Jan Rutkowski, Studia z dziejów wsi polskiej XVI-XVIII w., Warszawa: Państwowe Wydawnictwo Naukowe, 1956, 163.

49 The statutes of Piotrków issued by John I Olbracht in 1496, according to which one peasant and one son could be allowed to leave the village in order to pursue another profession for one year, provided that he was not the only son, see Stanisław Śreniowski, Zbiegostwo chłopów..., 76, 78-81, 83, 90-92, 96-97; Chłopskie poddaństwo..., 26.

50 See Kazimierz Tymieniecki, Sprawa chłopska w Polsce na przełomie XV i XVI w., In: Pierwsza Konferencja Metodologiczna Historyków Polskich. Przemówienia, referaty, dyskusja, vol. I, Warszawa 1953, 309; Cf. Kazimierz Tymieniecki, Zagadnienie niewoli..., 29-31, where this author takes a stand contradicting the thesis about the existence of slavery on Polish lands in the 15 th century. 
which he was born. Actually, this attachment to a peasant was made on an extra-legal basis. Later, one cannot find a constitution [after the Constitution of the Seym of Piotrków of 1496 - emphasis mine, M.K.] that would clearly specify this issue, but we also know that the peasant was commonly considered to be assigned to the land" 51 .

Nevertheless, in L. Kolankowski's opinion, according to the provisions of the Piotrków Sejm, the Polish nobility gained a decisive economic and, simultaneously with it, political advantage ${ }^{52}$.

\section{SEVERAL REMARKS ON THE COURT PROCEEDINGS CONCERNING THE FLIGHT OF PEASANTS}

Despite all the wide-ranging legislation, there was a constant movement of people from one lord to another, which was mainly due to the oppression experienced by the peasants, and thus was dictated by the need to change the economic conditions in which the peasants were living ${ }^{53}$. As S. Szczotka "Initially, peasants flee en masse to the Crown lands, because there are no manors there, or they are small" 54 . It should also be added, however, that towns were a strong magnet for Polish peasants, al-

51 Wojciech Hejnosz, Przypisanie chłopów do ziemi, In: Pierwsza Konferencja Metodologiczna Historyków Polskich. Przemówienia, referaty, dyskusja, vol. I, Warszawa: Państwowe Wydawnictwo Naukowe, 1953, 313.

52 See Ludwik Kolankowski, Polska Jagiellonów. Dzieje polityczne, Lwów: Księgarnia Gubrynowicz i Syn, 1936, 154.

53 Kazimierz Tymieniecki stresses that the term "flight" can be used only when a peasant left the land without fulfilling all the obligations or regulations and all the terms of the contract which connected him with the master of the land, while "the fact of large-scale leaving the masters' land by kmetones can be linked to the competition of hired labour, which took place both in towns and in the countryside", Kazimierz Tymieniecki, Sprawa chłopska..., 310. Janusz Deresiewicz has a similar opinion, Handel chłopami..., 176.

54 Stanisław Szczotka, Ocena folwarku. Przyczynki do formy oporu klasowego chłopów. Przyczynki do społecznych zagadnień reformacji, In: Pierwsza Konferencja Metodologiczna Historyków Polskich. Przemówienia, referaty, dyskusja, vol. I, Warszawa: Państwowe Wydawnictwo Naukowe, 1953, 492. 
though the number of completely certain sources, confirming penetration of the peasant element into the towns, is not large ${ }^{55}$.

Fugitive serfs or their offspring constituted the largest number of people who accepted the so-called voluntary serfdom, which in the Old Polish was referred to as "powzdanie się" ${ }^{56}$. The acceptance of servitude was in principle intended to last forever, but there were cases of "powzdanie się" for a more or less specific period of time ${ }^{57}$. Among the reasons for accepting servitude, as many as $80 \%$ of its incidents were caused by wedding female serfs $s^{58}$. As this author emphasises, "the fugitives who settled as "free" in another village, in conditions which seemed more favourable to them than before, wanted to become bound to the new environment by stronger knots, to ensure a better existence through marriage with the daughter of the settled kmeton, and after some time even entering his household, and finally to attract a stronger interest of the new master in defending himself against the possible claims of the old one"59.

55 See Kazimierz Tymieniecki, Sprawa chłopska..., 311, where the author points out that a peasant moving to a town was not forced to hide his origin, because the transfer to the town was a kind of social promotion for the peasant, and it should be noted that peasants settling in smaller towns, due to the agricultural character of those towns, often continued to cultivate the land. On the other hand, however, another thesis is put forward by Janusz Deresiewicz, who claims that the runaway subjects often changed their names and surnames in order to cover their traces, because neither a royal village nor a town provided security for them. It was logical because towns did not automatically grant town rights, even after many years, see Janusz Deresiewicz, Handel chłopami..., 193-194; cf. Stanisław Szczotka, Zwalnianie chłopów..., 278-286, and the author's comments on the influence of having a profession in the town before the peasants achieved liberalisation, Stanisław Szczotka, Zwalanie chłopów..., 286-294. For more information on the flight of burghers, see Maurycy Horn, Walka klasowa..., 172-176.

56 See Janusz Deresiewicz, Handel chłopami..., 134-135.

57 For more ways of becoming a serf see Włodzimierz Dworzaczek, „Dobrowolne” poddaństwo chłopów, Warszawa: Ludowa Spółdzielnia Wydawnicza, 1952, 43-60.

58 Cf. Janusz Deresiewicz, Handel chłopami..., 136-138. Włodzimierz Dworzacek analyses more widely the reasons for abandoning freedom, „Dobrowolne”..., 92-126.

59 Włodzimierz Dworzaczek, Zagadnienie dobrowolnego przyjmowania poddaństwa w XVII i XVIII w. In: Pierwsza Konferencja Metodologiczna Historyków Polskich. Przemówienia, referaty, dyskusja, volume I, Warszawa: Państwowe Wydawnictwo Naukowe, 1953, 496. 
Of course, the nobility, while gaining new hands for work, benefited from the "powzdanie się". According to W. Dworzaczek, the same landowner managed to gain even more than 40 new serfs. The remaining reasons $(20 \%)$ for "powzdanie się", except for the ones mentioned above $(80 \%)$, are cases of renouncing freedom in exchange for food or money given in the years of war disasters, for forbidding the damage caused unintentionally, overdue rents or debts ${ }^{60}$, or in connection with obtaining forgiveness for one's misdeeds. In Poland, the mass acceptance of serfdom dates back to 1656 , and the greatest intensity was in the years $1720-1730^{61}$.

Leaving the master's land by his serfs is connected, of course, with the fact that the demesne from the very beginning of its existence had in itself negative seeds ${ }^{62}$, which, in the opinion of S. Szczotka, resulted in the inhibition of the transition from the feudal system to the bourgeoisie system in Poland and, on the other hand, in the intensification of the peasantry's class struggle against feudalism, thus contributing to a serious threat to the existence the feudal lords ${ }^{63}$.

It was not easy to take legal action to recover a fugitive who had run away because of the high costs of the trial ${ }^{64}$. Anyway, pretrial activities such as the detention ${ }^{65}$ and arresting a fugitive were not easy. This was not the

60 See Janusz Deresiewicz, Handel chłopami..., 138-140.

${ }^{61}$ See Włodzimierz Dworzaczek, Zagadnienie..., 497.

62 See Stanisław Hoszowski, Rola folwarku pańszczyźnianego, In: Pierwsza Konferencja Metodologiczna Historyków Polskich. Przemówienia, referaty, dyskusja, volume I, Warszawa: Państwowe Wydawnictwo Naukowe, 1953, 490.

63 See Stanisław Szczotka, Ocena folwarku..., 491.

${ }^{64}$ As Jan Rutkowski writes, according to the popular opinion, trials concerning fugitives were often not even started, because either the fugitive could not be found or the trial would not pay off, Jan Rutkowski, Historia gospodarcza..., vol. I, 268; Maurycy Horn, Walka chłopów..., 43.

65 The requisitioning of the fugitive meant an official call from the master with whom the peasant had stayed after the escape to surrender him, done by the master from whom he had fled or on his behalf. It could have had direct consequences consisting in the release of the fugitive and then ended the case without trial. Typical pre-trial activities, according to Stanisław Śreniowski, include the announcement of the trial, the so-called arrest of the fugitive peasants and the "handing over" of them to the trial, which means that the master with whom the fugitive had taken refuge would keep the peasant till the trial and deliver him to the court, see Stanisław Śreniowski, Zbiegostwo chłopów..., 157, 161, 165-166. 
case when a serf fled to a nearby village - in such a case, trials were often initiated or the fugitive serf was simply brought directly to the village without the involvement of the judicial authorities ${ }^{66}$. It should be added that the flight of peasants was facilitated by manorial lords themselves ${ }^{67}$, who willingly accepted refugees, which was of course connected with the need for labour force ${ }^{68}$, but often the improvement of the fugitive's fate was only temporary because a similar fate often awaited them ${ }^{69}$.

As far as the nature of the trial of fugitive peasants is concerned, if someone who accepted the fugitive and did not want to give him up voluntarily, obviously risked a court dispute over the release of the fugitive $e^{70}$. In addition, however, the flight of peasants also led to court case concerning peasants' flight between the manorial lord the fugitive himself, where the lord personally judged the fugitive, found him guilty and decided on the punishment; I shall discuss the types of punishment later in the article.

The parties to a flight case before a public forum case were the lord demanding the fugitive (plaintiff) and the lord requested to release the fugitive (defendant). The subject of the dispute was, of course, the peasant himself. The public fugitive dispute was of a double nature, so it was a debt

66 See Janusz Deresiewicz, Handel chłopami..., 185-187; Celina Bobińska, Wieś niespokojna..., 106.

67 See Stanisław Śreniowski, Zbiegostwo chłopów..., 23-24.

68 The practice of flight created a separate category of people called "wykotcy", who occasionally or professionally were engaged in organising escapes of peasants, what was called "wykoczowanie". These people most frequently were peasants, who originated either from villages where the fugitives went, or from former fugitives, who knew the situation in the villages. Often wykotcy provided the refugees with their own means of transport, and organized the escape most often at night. Serious penalties (including the death penalty) were imposed for taking part in the organisation of the escape of serfs, but despite this, the practice reached significant proportions, see Stanisław Śreniowski, Zbiegostwo chłopów..., 128-135; Stanisław Szczotka, Uwagi o zbiegostwie..., 121; Maurycy Horn, Walka chłopów..., 53-54; Celina Bobińska, Wieś niespokojna..., 105.

69 See Historia chłopów..., 164.

70 According to Józef Putek, in the middle of the 17th century fugitives found it easy to find a place where they could be received, which made it necessary to issue a special constitution on fugitive serfs from the powiat districts of the Kraków Voivodeship, in the light of which the nobleman who employed a serf who was a stranger at his place risked a trial and paying compensation of 1000 grzywnas for accepting each fugitive peasant, Józef Putek, Miłościwe pany..., 94-96. 
collection process concerning the fugitive, and on the other hand, it was a lawsuit against the lord of the manor where the fugitive settled after his escape $^{71}$. One should remember, however, about the earlier competence of the patrimonial forum in cases concerning the flight of peasants ${ }^{72}$, where the dispute was between the master from whom the peasant had escaped and the peasant, which meant that in this case the peasant was a party to the dispute. However, when the flight case appeared at the public forum - when the patrimonial court in the village where the fugitive was staying did not take into account the claims of his former master; in that situation, the position of the parties in the dispute before the land court was taken by the manorial lords and the peasant became the subject of the dispute ${ }^{73}$.

In addition to criminal penalties that affected the life and health of the $\operatorname{serf}^{74}$, a civil penalty was also imposed on the fugitive, harming his property. In principle, in accordance with the lord's decision, a fleeing serf was exposed to the risk of confiscation of his movable and immovable property $^{75}$. As J. Rafacz emphasises, despite the harsh regulations, the practice was gentler, because neither the punishment of the gallows was applied nor the assets of the escaped peasant were always confiscated. In the worst case, his farm was taken away from him and his children, and handed over to his closest relative, thus recognizing the right of the family to the land that

71 See Stanisław Śreniowski, Zbiegostwo chłopów..., 177.

72 It is also important to remember about the Peasant Courts of Appeal in most Crown Starosties. These courts met at the royal court at the place where the king was staying. Such a court issued criminal acts for rural courts in the royal estates, see Ignacy Tadeusz Baranowski, Sądy referendarskie, Przegląd Historyczny 1(1909), 82-96.

73 For more on the competition of the competencies of public courts and patrimonial courts in peasant flight cases see Stanisław Śreniowski, Zbiegostwo chłopów..., 178-181, 190-204; Stanisław Szczotka, Uwagi o zbiegostwie..., 124-125; Kazimierz Tymieniecki, Sądownictwo w sprawach kmiecych a ustalanie się stanów na Mazowszu pod koniec wieków średnich, Poznań: Księgarnia Gebethner i Wolf, 1922, 6-13, 127-171. The forum agenda was often included in parliamentray instructions, see Instrukcja sejmiku wiszeńskiego posłom na sejm z 16 grudnia 1682 r., In: Akta grodzkie i ziemskie, volume XXII, prep. by Antoni Prochaska, Lwów: Towarzystwo Naukowe we Lwowie, 1914, 166.

74 See Księgi sądowe wiejskie klucza jazowskiego..., 158-159; Historia chłopów..., 165; Stanisław Szczotka, Uwagi o zbiegostwie..., 156-157.

75 See Józef Rafacz, Ustrój wsi..., 125-126; see Stanisław Szczotka, Uwagi o zbiegostwie..., 155-156; Kazimierz Tymieniecki, Sądownictwo..., 145. 
had been taken away ${ }^{76}$. Of the penalties applied against captured fugitives, prisons and shackles should be highlighted, in addition to forced labour, as they were often administered ${ }^{77}$.

\section{WAYS TO LEAVE A VILLAGE OTHER THAN FLEEING}

Obviously, peasants did not only flee or use "wychodzenie" [walking away $]^{78}$, or were abducted ${ }^{79}$, but also left villages when they were expelled against their will ("wyświecenie"), which was usually a punishment applied to thieves or persons who were accused of offenses against morals (rural harlots) ${ }^{80}$, or through sale. However, as J. Rafacz points out, the right to sell peasants should be understood in two ways. Firstly, one can sell a peasant with land and a cottage, "where he stays for a new owner", or secondly, "one gets rid of a peasant himself, separating his legal personality from the real estate". A peasant can either be sold with his land and house,

76 Księga gromadzka wsi Golcowa z lat 1618-1744, In: Księgi sądowe wiejskie, vol. I, Starodawne prawa polskiego pomniki, vol. XI, prep. by Bolesław Ulanowski, Kraków: Polska Akademia Umiejętności, 1921, 614-615; Księga gromadzka wsi Lubcza z lat 1457-1603, In: Księgi sądowe wiejskie, vol. II, Starodawne prawa polskiego pomniki, tom XII, prep. by Bolesław Ulanowski, Kraków: Polska Akademia Umiejętności, 1921, 216; Księga sądowa Uszwi dla wsi Zawady z lat 1619-1788, prep. by Adam Vetulani, Wrocław: Zakład Narodowy im. Ossolińskich Wydawnictwo Polskiej Akademii Nauk, 1957, 195-198, 203-204, 209-210, 215-216, 218-220; Księgi sądowe wiejskie klucza tąckiego z lat 1744-1811, prep. by Adam Vetulani, Wrocław-Warszawa-Kraków: Zakład Narodowy im. Ossolińskich Wydawnictwo Polskiej Akademii Nauk, 1963, 30-31, 70-71; Księga sądowa wsi Iwkowej z lat 1581-1809, prep. by Stanisław Płaza, Wrocław-Warszawa-Kraków: Zakład Narodowy im. Ossolińskich, 1969, 148-149; Ignacy Tadeusz Baranowski, "Ze studiów nad dziejami agrarnymi Polski. Stosunek chłopa do ziemi we wsi Małopolskiej w ostatnich wiekach Rzeczypospolitej”, Przegląd Historyczny 1(1912), 61.

77 See Józef Rafacz, Ustrój wsi..., 126.

78 Sometimes the manor house did not make it difficult for peasants who were not subject to serfdom to leave their village to earn their living. So the peasants did not run away, but simply "went out" to earn money and usually came back after the summer work season, after a year or several years, see Stanisław Śreniowski, Zbiegostwo chłopów..., 89-92; Celina Bobińska, Wieś niespokojna..., 98-99.

79 See Maurycy Horn, Walka chłopów..., 55-56.

80 See Jan Rutkowski, Studia z dziejów..., 163-164; Józef Rafacz, Ustrój wsi..., 84. 
or only the peasant is removed, detaching his legal personality from his property ${ }^{81}$. In the latter case, the peasant fell into the category of things, "objects which are freely disposed of with the application of certain legal provisions only, changing according to the era, economic conditions and race" ${ }^{\prime 2}$. It should be noted that the alienation of peasants took place in Poland mostly in the form of donations, whereas the object of the donations is peasants with or without land, and in the latter case the peasants are disposed of both without families and with families. However, in most cases the person who was sold a peasant without any immovable property ${ }^{83}$.

As J. Deresiewicz noted, the transfer (donation or resignation) could have been either a donation or an actual sale, because "in old Polish law less importance was attached to the issue of remuneration, while what was put in the foreground was the fact whether the transaction was perpetual or temporary. A less important issue was whether it was a sale (traditio seu venditio), a donation (donatio) or exchange (commutatio); these terms were used side by side in the same sense. By way of contrast, eternity and hereditability were emphasised" 84 . The author also points out that the form of the donations in question was often based on payment (remuneration), which is an argument that peasants were nevertheless sold and that the boundaries between donation and sale were sometimes fuzzy ${ }^{85}$.

As for the monetary value for which surfs were sold (taxa capitis), J. Deresiewicz states that "this taxa for a male peasant was 120 grzywnas, which was an equivalent of 192 zlotys, and for a woman 60 grzywnas, i.e. 96 zlotys", while depending on the region these taxa were lower (e.g. 100 and 50 grzywnas) ${ }^{86}$. However, payment in money by a surf was not a rule, because often remuneration took the form of remuneration in kind, such as various types of objects, livestock or even services in the form of e.g. renovation of a building ${ }^{87}$.

\footnotetext{
81 Józef Rafacz, Ustrój wsi..., 94.

82 Ibidem, 95.

83 See ibidem, 97-98; Józef Putek, Miłościwe pany..., 96.

84 Janusz Deresiewicz, Handel chłopami..., 210-211.

85 See ibidem, 217.

86 See ibidem, 228.

87 See ibidem, 245-248.
} 
Apart from the forms of payment for surfs mentioned above, there were, of course, non-cash transactions, i.e. a form of exchange of surfs ("a head for a head"), but sometimes some objects or livestock were added as compensation for the price for people ${ }^{88}$. In addition, what also happened was that surfs were lent - especially those specializing in some kind of work, leased with land, and pledged as a security for a cash loan, usually for a period of one year, where the peasant was a security (guarantee) for the return of this loan ${ }^{89}$. However, in all the cases mentioned above (sale, donation, exchange), a peasant who was the subject of the transaction ultimately often opted for an escape, which he saw as the only way to improve his material and economic situation, and often also his legal situation.

\section{CONCLUSION}

To conclude the discussion above, a number of key issues need to be addressed. First of all, it should be remembered that among the causes of peasants' flight from the power of feudal lords were both material considerations (poverty and various kinds of injustice suffered from the feudal lord) and those resulting from economic nature, i.e. a natural desire of a human to improve his or her economic situation. Both types of these causes should be treated as forms of social struggle of a class character and constitute a form of resistance to the system of feudal power and are thus subject to academic analysis. Secondly, it should be emphasized that despite the existence of broad legislation aimed at curbing the practice of becoming a person fleeing one' manorial lord, it did not diminish in the following centuries, but was even becoming more widespread, resulting in more detailed and repressive legal regulations relating to the problem of the flight of peasants, often being an expression of the personal legislation of the feudal lord ${ }^{90}$. Thirdly, attention should be paid to the modest amount of re-

88 See ibidem, 258.

89 See ibidem, 259-273.

90 It should be remembered that the manorial lord was a legislator and a judge, a guardian of the serfs and the holder of administrative, law enforcement and executive powers. He issued lord's ordinances, which appear e.g. in Kasina books (the village of Kasina) - the oldest gromada books dating back to 1513, under the name of statutes or de- 
search conducted so far into the nature of the trial of fugitive peasants, and in particular to the procedural forum in court cases concerning the flight of peasants ${ }^{91}$, which is, however, an excellent field of research for further legal analysis of the issue of the flight of peasants in the old Poland.

\section{REFERENCES}

Akta grodzkie i ziemskie. 1911. Prep. by Antoni Prochaska. Vol. XXI, Lwów: Galicyjski Wydział Krajowy.

Akta grodzkie i ziemskie. 1914. Prep. by Antoni Prochaska. Vol. XXII, Lwów: Towarzystwo Naukowe we Lwowie.

Akta grodzkie i ziemskie. 1928. Prep. by Antoni Prochaska. Vol. XXIII, Lwów: Towarzystwo Naukowe we Lwowie.

Akta grodzkie i ziemskie. 1935. Prep. by Wojciech Hejnosz. Vol. XXV, Lwów: Towarzystwo Naukowe we Lwowie.

Akta sejmikowe województwa krakowskiego 1932. Prep. by Stanisław Kutrzeba. Vol. I, Kraków: Polska Akademia Umiejętności.

Akta sejmikowe województwa krakowskiego. 1953. Prep. by Adam Przyboś. Vol. II, Kraków: Polska Akademia Umiejętności.

Akta sejmikowe województwa krakowskiego 1959. Prep. by Adam Przyboś. Vol. III, Wrocław-Kraków: Zakład Narodowy im. Ossolińskich Wydawnictwo Polskiej Akademii Nauk.

crees. Next to them, gromadas issued the following collection resolutions, see Bolesław Ulanowski, Wieś polska..., 14-15, 20-21.

91 In addition to the research made in this area years ago by Stanisław Śreniowski, Zbiegostwo chłopów..., 171-204, these threads were only discussed in the study by Aniela Kiełbicka, where the author presented interesting source material in the form of a table containing 1649 cases of flight in the area of the Kraków Voivodeship in a selected period. In a tabular list, the author included a topography of property territories according to their belonging to historical administrative units from which peasants fled, quoted the names and surnames of the owners and lease-holders of property and the names of the peasants who fled (their origin, family ties, status in the social structure of the village, etc.), as well as information about the towns to which a given peasant fled and the ownership of the village to which he fled, see Zbiegostwo chłopów w województwie krakowskim na przełomie XVI i XVII wieku, prep. by Aniela Kiełbicka, Wrocław: Zakład Narodowy im. Ossolińskich, $1989,37-155$. 
Księgi sądowe wiejskie 1921. Prep. by Bolesław Ulanowski. Vol. I-II, Starodawne prawa polskiego pomniki, vol. XI-XII, Kraków: Polska Akademia Umiejętności.

Księga sądowa Uszwi dla wsi Zawady z lat 1619-1788. 1957. Prep. by Adam Vetulani, Wrocław: Zakład Narodowy im. Ossolińskich Wydawnictwo Polskiej Akademii Nauk.

Księgi sądowe wiejskie klucza łąckiego z lat 1744-1811 1963. Prep. by Adam Vetulani, Wrocław-Warszawa-Kraków: Zakład Narodowy im. Ossolińskich Wydawnictwo Polskiej Akademii Nauk.

Księgi sądowe wiejskie klucza jazowskiego z lat 1663-1808. 1967. Prep. by Stanisław Grodziski, Wrocław-Warszawa-Kraków: Zakład Narodowy im. Ossolińskich Wydawnictwo Polskiej Akademii Nauk.

Księga sądowa wsi Iwkowej z lat 1581-1809. 1969. Prep. by Stanisław Płaza, Wrocław-Warszawa-Kraków: Zakład Narodowy im. Ossolińskich.

Volumina Legum. 1859. Vol. I-II, Petersburg: J. Ohryzko.

Baranowski, Bohdan. 1953. Ludzie luźni w południowo-wschodniej Wielkopolsce w XVII-XVIII wieku, Łódź: Zakład Narodowy im. Ossolińskich.

Baranowski, Ignacy Tadeusz. 1909. „Sądy referendarskie”, Przegląd Historyczny $1: 82-96$.

Baranowski, Ignacy Tadeusz. 1912. „Ze studiów nad dziejami agrarnymi Polski. Stosunek chłopa do ziemi we wsi Małopolskiej w ostatnich wiekach Rzeczypospolitej”, Przegląd Historyczny 1:55-69.

Bardach, Juliusz. 1964. Historia państwa i prawa Polski do połowy XV wieku, vol. I, ed. II, Warszawa: Państwowe Wydawnictwo Naukowe.

Bobińska, Celina. 1979. Wieś niespokojna. Studia małopolskie z XVIII-XIX wieku, Warszawa: Książka i Wiedza.

Chamerska, Halina. 1957. O położeniu i zbiegostwie czeladzi folwarcznej w Królestwie Polskim 1830-1864, Warszawa: Państwowe Wydawnictwo Naukowe.

Chłopskie poddaństwo w Polsce. 1898. Lwów: Naprzód.

Czernik, Stanisław. 1955. Z życia pańszczyźnianego w XVII wieku: materiały i szkice, Warszawa: Ludowa Spółdzielnia Wydawnicza.

Deresiewicz, Janusz. 1958. Handel chłopami w dawnej Rzeczypospolitej, Warszawa: Książka i Wiedza.

Dworzaczek, Włodzimierz. 1952. „Dobrowolne” poddaństwo chłopów, Warszawa: Ludowa Spółdzielnia Wydawnicza.

Dworzaczek, Włodzimierz. 1953. „Zagadnienie dobrowolnego przyjmowania poddaństwa w XVII i XVIII w.", In: Pierwsza Konferencja Metodologiczna Historyków Polskich. Przemówienia, referaty, dyskusja, vol. I, Warszawa: Państwowe Wydawnictwo Naukowe. 
Grodziski, Stanisław. 1961. Ludzie luźni: studium z historii państwa i prawa polskiego, Kraków: Uniwersytet Jagielloński.

Grodziski, Stanisław. 2000. „Poddani mieszani (sujets mixtes) na ziemiach polskich w latach 1772-1815”, In: Prawo wczoraj i dziś. Studia dedykowane Profesor Katarzynie Sójce-Zielińskiej w czterdziestolecie pracy naukowej. Ed. Grażyna Bałtruszajtys, Warszawa: „Liber”.

Grynwaser, Hipolit. 1951. „Kwestia agrarna i ruch wtościan w Królestwie Polskim w pierwszej połowie XIX wieku (1807-1860). Studium archiwalne”, In: Hipolit Grynwaser, Pisma, vol. II, Wrocław: Zakład Narodowy im. Ossolińskich.

Grynwaser, Hipolit. 1951. „Przywódcy i burzyciele włościan”, In: Hipolit Grynwaser, Pisma, vol. II, Wrocław: Zakład Narodowy im. Ossolińskich.

Grzybowski, Konstanty. 1956. „Burżuazja a obszarnicy w państwie obszarniczoburżuazyjnym ( $Z$ zagadnień ustroju społeczno-gospodarczego)”, Kwartalnik Historyczny 4-5:221-244.

Hejnosz, Wojciech. 1953. „Przypisanie chłopów do ziemi”, In: Pierwsza Konferencja Metodologiczna Historyków Polskich. Przemówienia, referaty, dyskusja, vol. I, Warszawa: Państwowe Wydawnictwo Naukowe.

Helcel, Antoni Zygmunt. 1856. „Starodawne prawa polskiego pomniki, vol. I, Warszawa: Księgarnia Gustawa Sennewalda.

Historia chłopów śląskich. 1979. Ed. Stefan Inglot, Warszawa: Ludowa Spółdzielnia Wydawnicza.

Horn, Maurycy. 1972. Walka klasowa i konflikty społeczne w miastach Rusi Czerwonej w latach 1600-1647 na tle stosunków gospodarczych, Wrocław: Zakład Narodowy im. Ossolińskich.

Horn, Maurycy. 1974. Walka chłopów czerwonoruskich z wyzyskiem feudalnym w latach 1600-1648. Part I: zbiegostwo i zbójnictwo karpackie, Opole: Wyższa Szkoła Pedagogiczna im. Powstańców Śląskich w Opolu.

Hoszowski, Stanisław. 1953. „Rola folwarku pańszczyźnianego”, In: Pierwsza Konferencja Metodologiczna Historyków Polskich. Przemówienia, referaty, dyskusja, vol. I, Warszawa: Państwowe Wydawnictwo Naukowe.

Hube, Romuald. 1881. Ustawodawstwo Kazimierza Wielkiego, Warszawa: Biblioteka Umiejętności Prawnych.

Hube, Romuald. 1886. Sądy: ich praktyka i stosunki prawne społeczeństwa w Polsce ku schyłkowi 14 wieku, Warszawa: Biblioteka Umiejętności Prawnych.

Kaczmarczyk, Zdzisław. 1939. Monarchia Kazimierza Wielkiego. Vol. I: organizacja państwa, Poznań: Księgarnia Akademicka.

Kaczmarczyk, Zdzisław. 1948. Kazimierz Wielki (1333-1370), Warszawa: Wydawnictwo S. Arcta. 
Kolankowski, Ludwik. 1936. Polska Jagiellonów. Dzieje polityczne, Lwów: Księgarnia Gubrynowicz i Syn.

Kuliszer, Józef. 1961. Powszechna historia gospodarcza średniowiecza i czasów nowożytnych, vol. I, Warszawa: Książka i Wiedza.

Kutrzeba, Stanisław. 1925. Historia źródeł dawnego prawa polskiego, vol. I, Lwów: Zakład Narodowy im. Ossolińskich.

Manteuffel, Tadeusz. 1948. „Problem feodalizmu polskiego”, „Przegląd Historyczny" 37:62-71.

Opas, Tomasz. 1974. "O kierunkach awansu społecznego chłopów z dóbr prywatnych w XVIII wieku”, In: Społeczeństwo polskie w XVIII i XIX w., vol. VI, Warszawa: Państwowe Wydawnictwo Naukowe.

Orłowski, Ryszard. 1959. „Opór włościan i formy walki klasowej w Ordynacji Zamojskiej w drugiej połowie XVIII stulecia", Annales Universitatis Mariae Curie-Skłodowska. Sectio F 5:139-177.

Putek, Józef. 1969. Miłościwe pany i krnąbrne chłopy włościany. Szkice i sylwetki z dziejów poddaństwa, pańszczyzny, grabieży wojskowych, procesów sądowych i innych form ucisku społecznego na dawnym pograniczu ślasko-polskim, Kraków: Ludowa Spółdzielnia Wydawnicza.

Rafacz. Józef. 1920. "Sprawa niewoli chłopskiej w dawnej Polsce", Przewodnik Naukowy i Literacki 48.

Rafacz, Józef. 1922. Ustrój wsi samorządnej małopolskiej w XVIII wieku, Lublin: Uniwersytet Lubelski.

Ruszel, Krzysztof. 1989. Sprawy chłopskie przed sądem dominialnym w Ninadowej w latach 1806-1843, Przemyśl: Krajowa Agencja Wydawnicza.

Rutkowski, Jan. 1947. Historia gospodarcza Polski, Vol. I: Czasy przedrozbiorowe, Poznań: Księgarnia Akademicka.

Rutkowski, Jan. 1956. Studia z dziejów wsi polskiej XVI-XVIII w., Warszawa: Państwowe Wydawnictwo Naukowe.

Szczotka, Stanisław. 1949. „Uwagi o zbiegostwie włościan w dawnej Polsce”, Rocznik Dziejów Społecznych i Gospodarczych 1949, vol. XI.

Szczotka, Stanisław. 1951. Z dziejów chłopów polskich, Warszawa: Ludowa Spółdzielnia Wydawnicza.

Szczotka, Stanisław. 1951. „Zwalnianie chłopów z poddaństwa w województwie krakowskim w latach 1572-1794", Czasopismo Prawno-Historyczne 3:243-303.

Szczotka, Stanisław. 1953. "Ocena folwarku. Przyczynki do formy oporu klasowego chłopów. Przyczynki do społecznych zagadnień reformacji”, In: Pierwsza Konferencja Metodologiczna Historyków Polskich. Przemówienia, referaty, dyskusja, vol. I, Warszawa: Państwowe Wydawnictwo Naukowe. 
Śreniowski, Stanisław. 1948. Zbiegostwo chłopów w dawnej Polsce jako zagadnienie ustroju społecznego, Warszawa: Spółdzielnia Wydawnicza „Książka”.

Tymieniecki, Kazimierz. 1922. Sądownictwo w sprawach kmiecych a ustalanie się stanów na Mazowszu pod koniec wieków średnich, Poznań: Księgarnia Gebethner i Wolf.

Tymieniecki, Kazimierz. 1933. Zagadnienie niewoli w Polsce u schyłku wieków średnich, Poznań: Poznańskie Towarzystwo Przyjaciół Nauk.

Tymieniecki, Kazimierz. 1953. Sprawa chłopska w Polsce na przełomie XV i XVI w., In: Pierwsza Konferencja Metodologiczna Historyków Polskich. Przemówienia, referaty, dyskusja, vol. I, Warszawa: Państwowe Wydawnictwo Naukowe.

Ulanowski, Bolesław. 1894. Wieś polska pod względem prawnym od wieku XVI do XVIII, Kraków: Akademia Umiejętności.

Uruszczak, Wacław. 1999. „Statuty Kazimierza Wielkiego jako źródło prawa polskiego", Studia z Dziejów Państwa i Prawa Polskiego 3:97-115.

Wróbel, Zdzisław. 1929. Zbójnictwo na Podhalu, Częstochowa: Drukarnia Udziałowa.

Zbiegostwo chłopów w województwie krakowskim na przełomie XVI i XVII wieku. 1989. Prep. by Aniela Kiełbicka, Wrocław: Zakład Narodowy im. Ossolińskich. 